\title{
SAP-FAMILY PARTNERSHIP FOCUSED ON PREVENTION AND DIMINISHING ABSENTEEISM IN PREDOLESCENT FROM THE REPUBLIC OF MOLDOVA
}

\begin{abstract}
The purpose of this paper is to characterize the means of work aimed at pedagogical and psychological assistance to children, teachers. The SAP program is aimed at preventing early school leaving, juvenile deviant behavior and managers as managers influencing child development.
\end{abstract}

Keywords: educational partnership, social services, family.

\section{Introduction}

The educational partnership is one of the key words of contemporary pedagogy. It is a concept and an attitude in the field of education (Băran-Pescaru, 2004). The analysis of educational practices on the achievement of educational partnerships between different social institutions, as well as social agents directly involved in the education of the young generation, demonstrates the presence of a large number of errors (Mîslițchi, Botnari, 2015).

We understand through educational partnership - a complex concept reflecting an attitude and a relationship of social agents who become partners in the field of education” (A. Şram) (Mîslițchi, Botnari, 2015). 
As an attitude, the educational partnership assumes:

- Acceptance of educational actions and influences;

- Equalizing opportunities to participate in a common educational action. As a relationship, the educational partnership implies:

- Optimal communication between the social agencies participating in education;

- Collaboration of education agents in various forms and modalities, orientation towards the formation of the child's personality;

- Cooperation in the field of interrelations and union of efforts to achieve joint educational actions; Interaction and "Feed-back" - the supported and accomplished by all partners.

The area of defining the educational partnership is generally stretched in the literature:

The educational partnership, by its essence, is not an invention of contemporary pedagogy. Well-outlined elements of the educational partnership we still certify in the works of ancient philosophers. Thus, Plato (427-347 B.C.) in his work Protagonor, Aristotle (384-322 B.C.). In his work Politics mentioned the necessity and significance of the unification of family, school and society forces, for the education of a person and a true citizen. (Mîslițchi, Botnari, 2015).

According to the assessments made by the scientists of the Ph. Aries, by Mause, Ed. Shorter, J.L. Flandrin, I.S. Kon, E.Stănciulescu the feeling of childhood and the feeling of the family was constituted gradually and simultaneously, one in conjunction with the other (Mîslițchi, Botnari, 2015).

In his works, Ph. Aries (1968) states that the emergence of childhood sentiment and the interest of parents for children's education are historically simultaneous with the development of school education. Thus the child is gradually placed in the center of the family, and the patrimonial family is replaced by the child centered (Mîslițchi, Botnari, 2015).

The educational partnership manifests itself as a social and pedagogical phenomenon involving the curricular approach of education, which focuses on respecting and "valorizing the diversity of the uniqueliness of every human being and multiculturality" (Vrasmas, 2008). Mircea Ştefan argues that the partnership represents cooperation in an action of common interest.

According to Sorin Cristea, a pedagogical partnership is understood (Cristea, 2013):

1. A commitment in a joint, negotiated action;

2. A contribution of resources, changes, contacts, associated networks in constructive terms;

3. A negotiation between the parties having the power to interrelate with a recognised interinhabitant; 
4. A collaborative agreement between equal partners working together to achieve their own interests by solving common problems;

5. An institutional framework for solving common problems through coherent action, leaving the definition of general objectives in a determined time, with the clear distribution of responsibilities and evaluation processes.

\section{Effective partnership}

An effective partnership involves not only joint decisions, designed, realization and monitoring, but also union efforts in respecting ethical norms, ensuring quality education for all students.

The family is the first educational factor in the child's life, it exercises the first influences on the development of the child and puts its mark on its entire personality. The first social values are transmitted by the family: "before benefiting from institution education, the child learns in the family". Families in modern society face high demands and some, from the desire to give them economic certainty, spend less time with children. In rural areas, parents do not have enough time to supervise their child in the family, so that children spend most of their intellectual, moral, and professional development in an institution framework, named school (Cuznețov, 2002).

Therefore, the partnership with the family is specially important, because family represents the psycho-pedagogical and moral environment most suited to the development of pupils, and the school takes up and continues this action to educate and socialize them (Mîslițchi, Botnari, 2015).

A successful partnership involves: identifying goals, common interests, useful to partners and the community; finding the best way to achieve the intended purpose; organization and management of available resources to achieve it; identifying the competences of the people involved in these projects in order to be able to use them to the fullest; the effective combination of different attitudes, approaches and techniques that may apply to different tasks; successful use of change for the benefit of the institution, in this case of the school and the community.

So partnership with the family reflects a collaborative relationship between the family and the educational institution, based on trust, goodwill, communication and cooperation, with the intent of a sharp development of the individuality and personality of children (Mîslițchi, Botnari, 2015). 


\section{Psycho-pedagogical Assistance Services and its beneficiaries}

In order to ensure the right to quality education for all children, the Republican Centre for Psycho-Pedagogical Assistance (CARP) has been established at national level, and at district/municipal level the rayon/municipal assistance service was created Psycho-pedagogical Assistance Services (SAP), the mission of both institutions is to ensure the right to quality education of all children (DECISION No. $732 \ldots$, 2013) .

The purpose of SAP is to provide psycho-pedagogical assistance in order to ensure access to the quality education of all children/pupils.

Beneficiaries of SAP services are:

a) All children, irrespective of the material state of the family, the environment of residence, ethnicity, spoken language, gender, age, health status, learning characteristics, criminal history, or other categories of children, young people and adults who, from Different reasons, are marginalised or excluded in the process of the accession and implementation of an education programme;

b) Teachers and support staff, psychologists, other specialists involved in the educational inclusion process, which operates within the framework of pre-school, primary and general secondary education institutions;

c) Local public authority;

d) The child's family.

One of the tasks of the SAP is to implement, school inclusion programmes in order to prevent school leaving and early school leaving, to prevent violence on the child in the family, school and community environment, to prevent juvenile delinquency and deviant behaviours, prevention of child trafficking and exploitation of children through work, supporting children left without parental care for school participation, prevention of child neglect, etc.;

One of the major problems in educational establishments is the absenteeism among pupils growing phenomenon ever more commonly encountered worldwide. Refusing to participate in studies significantly affects both people who neglect the educational system and the society they belong to. In this context, school absenteeism and its prevention are not only a problem of the educational system, but a problem of the whole society, which generates unemployment, poverty, increases delinquency and drug use, in other said, marks the economy of the country in general, and the present and future of many families, in particular.

Family relationships and composition - as an educational and facilitator environment or in charge of school attendance by children, the family can be one of the causes of absenteeism.

As an educational environment, the family can have shortcomings in the edu- 
cational part of the child's intellectual development (the need for the school for Personal development).

In order to strengthen the capacities and training of correct perceptions in addressing the child in the risk group, the Psycho-pedagogical Assistance Service consults and provides methodological assistance to pre-school, primary and secondary education institutions, multidisciplinary committees from educational institutions, teaching/supporting staff, psychologists, logopeds, other specialists interacting with the child, resource centres for inclusive education, families, parents or legal representatives of the child, local public authorities.

The educational partnership in favour of the child in the risk group with deviant behavior, in our case with school absenteeism, involved in the process of special and social inclusion, is considered the foundation on which it builds and supports its functionality the entire system of pedagogy.

Semantic Concepts - key in building and promoting partnerships must be: acceptance, communication, cooperation, coordination, efficiency, evolution, ect.

The educational partnership in favour of subjects in the risk group category is not an action of a sporadically and unique nature, but a continuous process based on natural principles and harmoniously framed in the act of Education for all children.

Educational partnerships are constituted and operated by the conjugated effort of each educational agent/actor - small and extended family, general education institutions, community social centres, through which could also be the services of psychopedagogical assistance. By mutual agreement and through permanent communication, each through the specific prism of its field of activity, educational agents develop and coordinate tactics, strategies, techniques, methods, processes of assisting children and their families, in the effort Integration into an institution of learning and society, creating conditions for the recovery and development of physical, intellectual, spiritual potential.

Contrary to a widespread opinion in society, an educational partnership has to gain not only children, but all the agencies involved, in other words - the whole society.

The family constitutes the essential component in achieving educational partnerships. Any forms of collaboration with parents are effective if the following conditions are complied with: systematically carried out; are based on a thorough structured action plan; Respond to the interests and needs of informing parents; they are oriented towards a clear purpose;

The partnership between the family and SAP is beneficial for both parties: Parents learn from SAP specialists (psychologist, teacher, Psycho-pedagogue, logoped) How to educate their child to meet their educational needs, and specialists Learn 
from parents the information about the child (parents always know the child best, even for the fact that they are with him since birth, spend more time with him, notice him in different poses).

The foundation on which it builds, the Edifa of "Family partnership - SAP is the unit of values, for purposes, of purpose. And, "The alloy" that cements This partnership consists of positive thinking, unconditional love for the child, tolerance, clear understanding of roles, mutual trust, open communication and, only in the least, from the material support Provided by the family to the instructiveeducational process, it is not compulsory for the efficient conduct of the partnership activities (Mîslițchi, Botnari, 2015).

\section{Family Partnership project}

SAP-Family Partnership project "with small steps we do great things" focused on diminishing absenteeism in preteens

Partners:

1. SAP Specialists - psychologist, logoped, psychopedagogue, pedagogue primary and gymnasium classes;

2. Parents of preteens with absenteeism.

Duration period: 6 months

Argument: "With small steps we do great things" is an SAP-family partnership project on the Prevention and mitigation of the phenomenon of school absenteeism, because in recent years there has been an accelerated rate of student absenteeism. The project aims to integrate students with relationships/behavioral problems with absences of 3 consecutive days or 10 hours unmotivated with an external locus, through the team work of SAP specialists and the family of these children, in the class group. Through activities intended for parents or guardians of these children with increased vulnerability and not least by various specific psychological counselling activities aimed at students at risk of school abandonment.

The mutations in society and in the contemporary family (economic problems, problems of relationship between parents and children, reduced time with family, redistribution of roles, social and emotional support reduced, professional overloading of Parents or work abroad, etc.), causes more emotional problems in children than in the past and thus the frequency of school absenteeism is increasing.

Absenteeism becomes a social problem, a late signal of the existence of problems, a conduct that reflects the structured attitude of lack of interest, motivation, confidence in school education. 
Unfortunately, absenteeism is growing, especially at the gymnasium level, and ignoring or excessive punishment can only contribute to chronicization of the phenomenon.

This change in attitude does not appear sharply. There are always relevant indices of its occurrence. Any failure that is not observed in time can train an inadaptation process. The pupil resigned or waives, becoming indifferent to the school or rebelling against the insuccesses that he fails to overcome, tries certain compensations by which he wants to prove to himself that he can succeed in some things, which Sometimes it leads to unrulable acts or to avoid certain hours.

One of the basic elements of the partnership project will be the development of the locus control phenomenon for not coming pupils, which is the way a person perceives the world he lives in. Depending on its orientation, the pupil perceives whether the world is open to change, or is closed, and acts on it randomly. Pupils will be given attention to the possibility of achieving the desired objectives, thus empowering them to themselves and their future. A pupil involved in his own education will be a motivated student to complete his studies, so learning situations must be related to the real aspects of life.

Another aspect to be placed on the project is to develop the potential of educogen in the parents of not coming students. There are many cases where - with a despicable negligence - parents send their undisciplinated children to school to receive the education they should have given home. The obstacles to the relationship of psycho-pedagogical assistance to the family can be behavioural (the indifference of parents to the teaching process and the school performance of the child), or material order (meetings with SAP specialists require a Material and time effort on the part of parents). This situation shows the need to support parents in order to align educational purposes in favour of forming children's personality. The support given to parents covers three strands of action: a) emotional support (giving parents the opportunity to expression emotions, without criticism or conviction; informational support (give parents the opportunity to understand their own situation and their child's education); Instrumental support (provide them with means, techniques for solving problems related to child education).

For this purpose a dialogue between SAP specialists and parents is necessary. From the perspective of a systemic analysis, parents ' education appears as a dimension of permanent education and, of course, adult education.

The SAP Partnership Project - the family entitled, with small steps we do great things has taken shape by the desire and the common need of SAP specialists and parents to communicate effectively all the child, half of his time in an institution of General education and the other half in the middle of the family. 
Strengths:

- Mobilization of parents;

- Ensuring the opportunity to develop educational skills in parents; Addressing theoretical and practical aspects related to the education of their own children;

- Exchanges of experience;

- Create a school of parents in the district for discussing the problems that family and child meet during the educational course.

Weaknesses:

- The possibility for some parents not to treat this project with the same interest.

- Parents leaving abroad and children left in the care of the grandparents.

\section{Opportunities:}

- Good relationships for parents collaboration - SAP;

- Providing support services from SAP specialists (psychologist, logoped, Psychopedagogue, pedagogue) to pupils, parents of socially vulnerable families with absenteeism and risk of school abandonment;

Purpose: To support the pupil and the family in order to develop the pre-teens and to ensure the participation of parents in the education of their children.

Objectives:

- Developing parents ' training activities;

- Training of capacity and partnership practices in relationships from preteen, family and SAP specialists;

- Developing positive attitudes and fair social perceptions of the problem of developing and educing absent pupils, as well as eliminating discrimination of any kind;

- Identificarea rolurilor parentale și responsabilizarea părinților;

- Developing the educational competences of parents;

- Identify and conduct activities to support the SAP-family partnership.

Beneficiaries:

- Direct: Parents, SAP specialists (psychologist, logoped, Psychopedagogue, pedagogue Primary and gymnasium classes);

- Indirect: Secondary school teachers, students with absenteeism and risk of abandonment.

Expected results:

- A lot of involvement, openness and flexibility in the activities carried out by SAP specialists from parents and pupils; 
- Revision of the priorities by the absent preteens;

- Stricter monitoring of school absences and performances by parents;

- To acquire theoretical aspects of children's education;

- Direct involvement of parents in educational instructic activity.

Project Description:

During the course of this project there were carried out activities to advise families on educational topics, the pupils were framed in the development activities of locus internal control as a means of emotional and behavioral self-realization and motivation of learning. SAP specialists have pursued the evolution of each student within the educational Partnership project, correlated with behaviours and attitudes manifested in the family.

\begin{tabular}{|c|c|c|c|c|c|c|}
\hline N. & $\begin{array}{l}\text { Partnership } \\
\text { form }\end{array}$ & Theme & Objectives & Content & $\begin{array}{l}\text { Date of } \\
\text { deploy- } \\
\text { ment }\end{array}$ & $\begin{array}{l}\text { Respon- } \\
\text { sible }\end{array}$ \\
\hline 1 & Round table & $\begin{array}{l}\text { The opportu- } \\
\text { nities of the } \\
\text { SAP-family } \\
\text { partnership, } \\
\text { in training } \\
\text { to parents of } \\
\text { educogenic } \\
\text { skills, to pu- } \\
\text { pils emotional } \\
\text { and behav- } \\
\text { ioral self-real- } \\
\text { ization skills } \\
\text { and learning } \\
\text { motivation. }\end{array}$ & $\begin{array}{l}\text { - Identifying the } \\
\text { parents, opinion } \\
\text { on the current is- } \\
\text { sue of the project;- } \\
\text { Motivating part- } \\
\text { ners for effective } \\
\text { involvement in the } \\
\text { proposed educa- } \\
\text { tional partnership } \\
\text { project; }\end{array}$ & $\begin{array}{l}\text { Opportunities of- } \\
\text { fered by the proj- } \\
\text { ect in the training } \\
\text { of the educcogenic } \\
\text { skills of parents }\end{array}$ & January & $\begin{array}{l}\text { SAP } \\
\text { Specialists }\end{array}$ \\
\hline 2 & $\begin{array}{l}\text { Lectorate for } \\
\text { teachers and } \\
\text { parents }\end{array}$ & $\begin{array}{l}\text { Education in } \\
\text { our life }\end{array}$ & $\begin{array}{l}\text { - To explain the } \\
\text { importance of edu- } \\
\text { cation in personal } \\
\text { and professional } \\
\text { development; -to } \\
\text { present personal } \\
\text { experiences regard- } \\
\text { ing education. }\end{array}$ & $\begin{array}{l}\text { Life situations } \\
\text { Poster "Education" } \\
\text { The fruits of edu- } \\
\text { cation }\end{array}$ & January & $\begin{array}{l}\text { SAP Psy- } \\
\text { chologists }\end{array}$ \\
\hline
\end{tabular}




\begin{tabular}{|c|c|c|c|c|c|c|}
\hline 3. & $\begin{array}{l}\text { Workshop with } \\
\text { teachers and } \\
\text { parents }\end{array}$ & $\begin{array}{l}\text { Motivation } \\
\text { for education }\end{array}$ & $\begin{array}{l}\text { - To argue motiva- } \\
\text { tion for learning } \\
\text { and education; } \\
\text {-To Identify simple } \\
\text { motivational tech- } \\
\text { nics }\end{array}$ & $\begin{array}{l}\text { Exercise "Re- } \\
\text { marks" Case study, } \\
\text { motivated positive/ } \\
\text { motivated negative } \\
\text { Teamwork, Role } \\
\text { Playing: balloons } \\
\text { that lift you up }\end{array}$ & February & $\begin{array}{l}\text { Psy- } \\
\text { chologist/ } \\
\text { Teacher } \\
\text { SAP }\end{array}$ \\
\hline 4 & $\begin{array}{l}\text { Psychopeda- } \\
\text { gogical Group } \\
\text { consultation } \\
\text { with absent } \\
\text { students with } \\
\text { risk of aban- } \\
\text { donment }\end{array}$ & $\begin{array}{l}\text { For what we } \\
\text { need educa- } \\
\text { tion/training? }\end{array}$ & $\begin{array}{l}\text {-to present con- } \\
\text { crete results of } \\
\text { real-life education; } \\
\text {-to develop an } \\
\text { action plan for } \\
\text { the development } \\
\text { of the educational } \\
\text { route }\end{array}$ & $\begin{array}{l}\text { Braistormingul } \\
\text { method } \\
\text { "What I like/don't' } \\
\text { like at school ?" } \\
\text { Team work "The } \\
\text { Importance and } \\
\text { the message of } \\
\text { education" } \\
\text { Hex of motivation } \\
\text { Elaboration of the } \\
\text { 5-step action plan } \\
\text { for involvement in } \\
\text { school life }\end{array}$ & February & $\begin{array}{l}\text { Psycholo- } \\
\text { gist/ } \\
\text { Psy- } \\
\text { chopeda- } \\
\text { gog SAP }\end{array}$ \\
\hline 5 & $\begin{array}{l}\text { Theoretical } \\
\text { Seminar with } \\
\text { parents(activity } \\
\text { taken from the } \\
\text { SAP activity } \\
\text { plan) }\end{array}$ & $\begin{array}{l}\text { The role of } \\
\text { parents in } \\
\text { increasing } \\
\text { and educating } \\
\text { a harmonious } \\
\text { personality }\end{array}$ & $\begin{array}{l}\text {-Familiarise par- } \\
\text { ents with the im- } \\
\text { portance of their } \\
\text { involvement in the } \\
\text { development of } \\
\text { their own children. }\end{array}$ & $\begin{array}{l}\text { The specifics of the } \\
\text { preadolescent age- } \\
\text { The importance } \\
\text { of effective com- } \\
\text { munication at the } \\
\text { current stage. }\end{array}$ & March & $\begin{array}{l}\text { Psycholo- } \\
\text { gist SAP }\end{array}$ \\
\hline 6. & $\begin{array}{l}\text { Workshop with } \\
\text { parents and } \\
\text { absent students }\end{array}$ & $\begin{array}{l}\text { Emotional } \\
\text { and behav- } \\
\text { ioral self- } \\
\text { management; }\end{array}$ & $\begin{array}{l}\text {-involvement } \\
\text { in the proposed } \\
\text { practical activities;- } \\
\text { Identification of } \\
\text { effective methods } \\
\text { of self/emotional } \\
\text { adjustment. }\end{array}$ & $\begin{array}{l}\text { Designing a Life } \\
\text { Event } \\
\text { Team Work ”Up } \\
\text { and Down” } \\
\text { Exercise,, scale of } \\
\text { events „Analysis } \\
\text { of some film se- } \\
\text { quences. }\end{array}$ & March & $\begin{array}{l}\text { Psycholo- } \\
\text { gist SAP }\end{array}$ \\
\hline
\end{tabular}




\begin{tabular}{|c|c|c|c|c|c|c|}
\hline 7 & $\begin{array}{l}\text { Theoretical- } \\
\text { Practical Semi- } \\
\text { nar }\end{array}$ & $\begin{array}{l}\text { The impor- } \\
\text { tance of com- } \\
\text { munication }\end{array}$ & $\begin{array}{l}\text {-to argue the } \\
\text { importance } \\
\text { of effective } \\
\text { communication;- } \\
\text { to practice effective } \\
\text { communication } \\
\text { techniques }\end{array}$ & $\begin{array}{l}\text { Exercise Listen } \\
\text { each other" } \\
\text { Role play,, dolls } \\
\text { The Decalogue of } \\
\text { communication: } \\
\text { Developing a set } \\
\text { of } 10 \text { rules in an } \\
\text { effective commu- } \\
\text { nication. }\end{array}$ & April & $\begin{array}{l}\text { Psycholo- } \\
\text { gist/ } \\
\text { Psy- } \\
\text { chopeda- } \\
\text { gog }\end{array}$ \\
\hline 8 & $\begin{array}{l}\text { Round Table- } \\
\text { ParentsSec- } \\
\text { ondary school } \\
\text { teachers, Ab- } \\
\text { sent students }\end{array}$ & $\begin{array}{l}\text { "Jewelry and } \\
\text { crafts" }\end{array}$ & $\begin{array}{l}\text {-Analyse the occu- } \\
\text { pations practiced } \\
\text { in the community; } \\
\text {-Identify future } \\
\text { professional activi- } \\
\text { ties }\end{array}$ & $\begin{array}{l}\text { Braistorming: } \\
\text { What is work for } \\
\text { You? } \\
\text { Meditation: } \\
\text { "Maybe I will do } \\
\text { it, if... } \\
\text { Creative Work- } \\
\text { shop: Products fair }\end{array}$ & May & $\begin{array}{l}\text { Psycholo- } \\
\text { gist/ } \\
\text { Psy- } \\
\text { chopeda- } \\
\text { gog SAP }\end{array}$ \\
\hline 9 & $\begin{array}{l}\text { Psychopeda- } \\
\text { gogical Group } \\
\text { consultation } \\
\text { with parents } \\
\text { and pupils }\end{array}$ & $\begin{array}{l}\text { Decisions are } \\
\text { at our }\end{array}$ & $\begin{array}{l}\text {-To identify the } \\
\text { most important } \\
\text { personal decisions; } \\
\text {-To apply the steps } \\
\text { of taking a deci- } \\
\text { sion in different } \\
\text { life situations }\end{array}$ & $\begin{array}{l}\text { Exercise "Life } \\
\text { decisions" } \\
\text { Collage "Meanings } \\
\text { and purposes in } \\
\text { life" } \\
\text { Art-creative } \\
\text { technique } \\
\text { "Dream", }\end{array}$ & May & $\begin{array}{l}\text { Psycholo- } \\
\text { gist SAP }\end{array}$ \\
\hline 10 & $\begin{array}{l}\text { TableRound } \\
\text { with parents, } \\
\text { SAP specialists, } \\
\text { school teachers }\end{array}$ & $\begin{array}{l}\text { The impact of } \\
\text { SAP-family } \\
\text { cooperation } \\
\text { on the train- } \\
\text { ing of parents, } \\
\text { educogenic } \\
\text { skills and } \\
\text { learning } \\
\text { motivation } \\
\text { for absent } \\
\text { students }\end{array}$ & $\begin{array}{l}\text { Impact assessment } \\
\text { of the project on } \\
\text { beneficiaries }\end{array}$ & $\begin{array}{l}\text {-Exchange of im- } \\
\text { pressions between } \\
\text { the educational } \\
\text { project partners; } \\
\text {-Forms of conclu- } \\
\text { sions on the im- } \\
\text { pact of the project } \\
\text { on partners. }\end{array}$ & June & $\begin{array}{l}\text { SAP spe- } \\
\text { cialists }\end{array}$ \\
\hline
\end{tabular}


Media coverage: presentation of project activities in seminars organized at the level of educational institutions.

Dissemination of the results: popularization of the idea of the realization of the educational partnership SAP - family and presentation of the project results at the methodical meetings, scientific conferences.

Evaluation:

a) Assessing the involvement and interest of parents in the proposed project;

- the way: using the observation method, the investigation.

b) Assessing the impact of the project on locus development of internal control in absenteeism as a means of emotional and behavioral self-regulation and learning motivation;

- the way: using the test method by applying the Multidimensional Scale of Children's Control Perception - SMPCC;

c) Final evaluation.

- the way: to carry out a final analysis of the project in order to show the relationship between the proposed objectives and the certified results; portfolios.

\section{Conclusions}

1. Absenteeism is not only a result of school failure but rather a consequence of social and academic problems that often arise at the beginning of schooling, suggesting the need for early intervention.

2. Factors that generate absenteeism are amplified by lack of support and resources in families. In order to reduce the absenteeism rate it is necessary to assist students in solving the academic and social problems they face and to improve the framework that generates this phenomenon.

3. Students' participation in a project of educational partnership based on psychological counseling and active involvement of parents in educational partnership projects will reduce the problem of school absenteeism leads us to the conclusion that such educational partnership projects is more than necessary and useful in schools in our country.

\section{References}

Băran-Pescaru A. (2004). Partnership in education: family-school-community. Bucharest: Aramis Print. 
Cristea S. (2013). Partnership in Education. Theory and Educational Practice Magazine Didactica Pro. no. 3 (79).

Cristea S. (2000). Pedagogy Dictionary. Chisinau-Bucharest: Editorial Group Litera.

Cuznețov L. (2002). Psycho-pedagogical and ethical dimensions of the educational partnership: Methodological guide. Chişinău: U.P.S. "I. Creangă”.

DECISION No. 732 of 16.09.2013 on the Republican Center for Psycho-pedagogical Assistance and the District / Municipal Service of Psycho-pedagogical Assistance.

Mîslițchi V., Botnari V. (2015). Family Educational Partnership - Kindergarten School: Methodological Guide: Tiraspol State University, Department of Psychopedagogy and Preschool Education. Chișinău: Market Pulse.

Vrasmas E. (2008). Educational partnership - a condition for the efficiency of school and community-based socio-educational interventions. In: Socio-educational intervention as support for parents. Bucharest: Aramis Print.

\section{Program SAP skupiony na zapobieganiu i umniejszaniu absencji u dzieci w Republice Mołdawii}

\section{Streszczenie}

Celem tego artykułu jest scharakteryzowanie programów mających na celu pomoc pedagogiczną i psychologiczną dzieciom, nauczycielom. Program SAP ma na celu zapobieganie przedwczesnemu kończeniu edukacji, zachowaniom dewiacyjnym nieletnich oraz wzmocnienie rodziny jako instytucji mającej największy wpływ na rozwój dziecka.

Słowa kluczowe: partnerstwo edukacyjne, usługi społeczne, rodzina. 